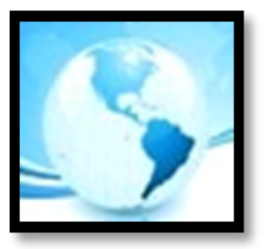

MALAYSIAN ONLINE JOURNAL OF

EDUCATIONAL MANAGEMENT

(MOJEM)

July 2019, VOLUME 7, ISSUE 3, 64 - 79

E-ISSN NO: $2289-4489$

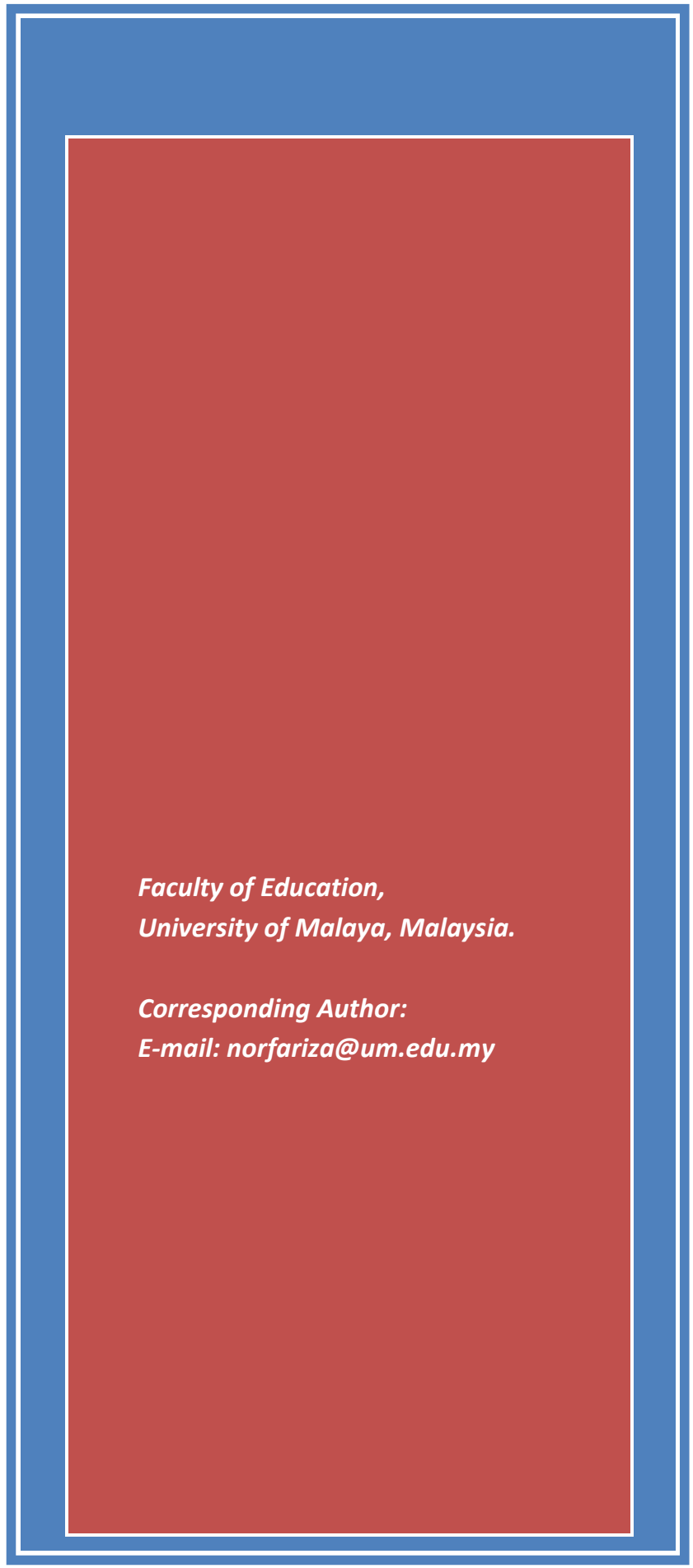

\title{
MANAGEMENT OF ROLE STRESS AMONG THE MALAYSIAN PRIMARY SCHOOL TEACHERS
}

Mohd Faizal Hassan, Hamidah Sulaiman (PhD), Ghazali Darusalam (PhD), Aini Arifah Abdul Karim \& Norfariza Mohd Radzi (PhD)

\begin{abstract}
The management of role stress is becoming more dominant issue in the career life of teachers due to various roles that teachers need to play in their job. Among the factors of role stress are role conflicts, role ambiguity and role overload. The main purpose of this research is to study the influence of selected factors such as role conflict factor, role ambiguity and role overload on role stress among the Malaysian National Primary School teachers. This study was designed by utilizing the quantitative approach. The instrument used was a questionnaire which has been adapted from various relevant researchers. A total of 150 teachers were randomly selected as respondents and the data obtained were analysed using SPSS for descriptive statistics and Smart PLS for the inferential statistics. The findings show that the level of stress was at moderate level. In addition, the findings indicate that there is a significant relationship between role conflicts $(\beta=0.212, t=2.640, P=0.009)$, role ambiguity $(\beta=0.219$, $t=2.701, P=0.007)$ and role overload $(B=0.372, t=4.364, P=0.000)$ to role stress. As a conclusion, this study demonstrates that role conflicts, role ambiguity and role overload have a major impact to the role stress of teachers in Malaysia. It is hoped that through this study, various stakeholders such as schools, the district education offices as well as the Ministry of Education will be able to assist in planning and organizing efforts to address the role stress issues in order to produce highly qualified teachers.
\end{abstract}

Keywords: Stress Management, Role Stress, Role Conflict, Role Ambiguity, Role Overload, Teachers, Malaysia 


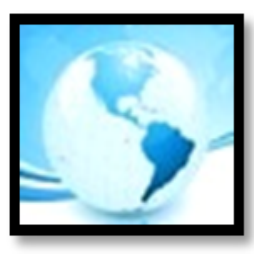

MALAYSIAN ONLINE JOURNAL OF

EDUCATIONAL MANAGEMENT

(MOJEM)

\section{INTRODUCTION}

Education is a big agenda that can influence the quality and civilization of a nation. A nation is considered backwards if it does not have a good education system. Knowledgeable individuals and societies who appreciate knowledge as a way of life will make it easier to make the right decisions (Ministry of Education Malaysia, 2013). Therefore, quality education is believed to produce human capital capable of critical thinking, creativity, innovation and willing to become k-workers to the nation to deal with global challenges. Hence, the education sector needs to transform and always strive to move forward to improve the quality of education in addressing these challenges.

The Malaysian Education Development Plan (PPPM) 2013 - 2025 is one of the Ministry of Education's comprehensive education plans to improve education status through transformation of education parallel with other countries in line with the progress of this borderless world. In realizing these goals, the quality of teachers is the most appropriate channel for the transformation of the national education system (Ministry of Education Malaysia, 2013). There are many findings regarding the quality of teachers which have proven that the role and quality of the teacher are very important in the success of the students. Even Barber and Mourshed (2007) have stated that the quality of the education system in a country could not exceed the quality of the teacher.

However, in the efforts of improving teachers' performance and quality, the challenges that teachers have to face in the education world are inevitable and increasingly challenging. One issue that cannot be ignored is stress among teachers. According to Mohd Fadzli Abu Bakar, Janet Ho Siew Ching, Irdiana Syeriza Hussein and Nazrah Jamaludin (2005), the current flow of education has pushed teachers to work hard to achieve high demand for education. In addition, Saedah Siraj, M. Sani Ibrahim and Rajendran, N. (2012) have also highlighted that the one of the challenges faced by teachers today is equipping themselves with knowledge and skills such as information technology and communication skills. Other than that, they also have to address discipline issues and social phenomena among students, school management, as well as meeting the high expectations by the community and many more.

Education is perceived as an instrument to empower people and societies for success and achievement. Hence, qualified educators are the ones who will provide the best learning experience besides producing good human capital that will benefit the nations in future. However, in today's challenging career world, it is inevitable for the teachers to escape from the stress and the pressure of the job. In the current challenging professional world, stress or job stress is inevitable and each individual has different interpretations of stress because each has a different understanding (Nur Izzaty Mohamad, Azman Ismail, Mohamad Shahril Azwan Mohamad Rozi, \& Sholihien Ahmad, 2015). It is not surprising that teachers are facing stress in their work too. This can be proven by the numerous studies and discussions on job stress among teachers in the recent years (Lucchetti et al., 2014; lyer \& Mahesh, 2015; Zahra, Mohammad Abdi, Reza, Mostafa, Vahid, \& Hesam, 2016).

In the context of stress or role stress among teachers, it refers to experiences that teachers do not like in terms of emotions such as stress, depression, worry, anger and everything related to teacher work (Mohd Fadzli et al., 2005). Stress among teachers is increasingly complex and challenging where teachers are required to carry out academic workloads such as teaching, should also provide exam questions, fill out pupils' arrivals, discipline books, teaching preparatory books, student health forms, student progress records, clubs and associations as well as conducting sports preparations and other events. Norashid Othman and Hamzah Md. Omar (2014) said that teachers' academic duties are also charged with non-academic tasks related to administrative administration, student affairs and co-curriculum management. Hence, teachers are exposed to high risk of experiencing stress which can ultimately lead to more serious conditions of chronic mental illness such as bipolar, extreme anxiety and depression. 


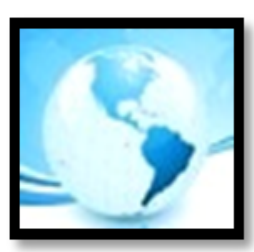

\section{MALAYSIAN ONLINE JOURNAL OF EDUCATIONAL MANAGEMENT (MOJEM)}

Abdullah Md. Din (2011) states that in the era of globalization, this borderless world has seen the task and role of teachers become more challenging. This challenging situation has led to various implications and effects on teachers who eventually led to stress or stress issues. Great Life Physio and Rehabilitations (2012) research found that teachers' profession was ranked fourth most stressful or stressful career after police profession, prison officials and nurses. Even his position above the military profession was fifth. While the study by Abang (2012) found that 30 percent of the 280,000 teachers in Malaysia were burdened with external duties and often unable to concentrate fully on their duties as a result of their role in conflict with their respective role conflicts. In addition, the study by the National Teaching Service Union, NUTP (2017) found that 70 percent of 9,000 teachers in Malaysia were under pressure.

Richards (2012) emphasizes that when a teacher experiences stress within a long period of time can undermine mental and physical well-being and seeks to significantly weaken the teacher's profession and student performance. This is because stress can affect teachers' teaching quality and commitment. It is supported by Weisberg and Sagie (1999), stating that stress also affects mental and physical health problems and influences the effectiveness of teacher relationships with students as well as affecting the quality of education. Based on the experience of the role of stress in this academic field, it has been shown clearly that academicians have a role in burden (Beehr, Walsh, \& Taber, 1976). Role stress will be present when the role expectation is greater than the ability and motivation to perform individual tasks (Conley \& You, 2013; Rizzo, House, \& Lirtzman, 1970).

Thus, based on issues related to this matter, this paper seeks to address the following research questions:

1. What is the level of stress among the national primary school teachers?

2. What are the relationships between the variables of role conflict, role ambiguity and role overload with role stress among national primary school teachers?

By responding to the questions of this study, it can provide an overview of the role stress phenomenon among teachers. It can also prove stress issues are inevitable among teachers. The stress issue has caused many unnecessary negative impacts on the country's education system. If this issue remained untouched, then the nation's desire to produce quality human capital will come to an avail. Hence, the issue of stress among teachers should be given dire attention by the government especially the Ministry of Education.

\section{THEORETICAL FOUNDATION}

In discussing the issue of role stress among teachers, researchers have made some comparison with reference to several previous studies. Among the past studies that had a major impact on this issue were the study done by Richards (2012). This study was conducted among 1,201 teachers teaching in the United States. The level of stress can be seen clearly in most of the elements measured in this study. Among the elements that gave a huge impact to stress among the teachers is the overwhelming commitment with role overload that some even have to bring their work home in order to complete them. In addition, elements of conflict and ambiguous with their respective roles also have an impact on stress among teachers.

Another study by Nagra and Arora (2013) on 216 teachers in Jalandhar and Hoshiarpur College, India found that the level of stress among them was moderate. However, the level of stress between male and female indicated that stress among women teachers is slightly higher than male teachers. A study conducted among Israeli teachers by Fadia M. Nasser (2015) which involved 425 teachers comprising of 48 per cent of Jewish teachers and 52 per cent Arabic teachers showed that the level of stress among these teachers is moderate. Nevertheless, the comparison between teachers according to race found that Jewish teachers were experiencing rather a higher level of stress compared to the Arabic teachers. 


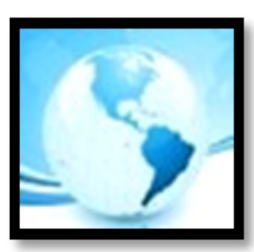

\section{MALAYSIAN ONLINE JOURNAL OF EDUCATIONAL MANAGEMENT (MOJEM)}

Johari Hassan and Noornazifah Md. Suandi (2012) conducted a study on 118 teachers from the national primary schools in Permas Jaya, Johor. The findings show that the level of stress among these teachers is also at moderate level. This study elaborated on other factors that influence the level of stress such as workload, interpersonal relationship, student problem and others. The findings of the Tajulashikin Jumahat, Fazura Mohd Noor and Mohd Burhan Ibrahim (2017) conducted on 186 Mubaligh primary school teachers in Kuala Lumpur found that 59.7 per cent of teachers experienced moderate stress.

In addition, a research by Norashid Othman and Hamzah Md. Omar (2014) on 193 teachers from three selected schools in the Ranau district of Sabah found that the burden of teachers' duties was high. This study categorizes the duties of teachers into two components namely academic and non-academic tasks. In this study, the task load level for these two components is high. The burden of assignment whether academic or non-academic tasks shows a negative relationship with teachers' motivation

In another study carried out by Ooi and Aziah Ismail (2015) with 289 national school primary teachers and chinese schools, the teachers claimed that they had been subjected to stress due to high role burden as well as other factors such as role ambiguity, role conflicts and others. In addition, there are also studies conducted at primary schools and Chinese national primary schools. The study by Ooi and Aziah Ismail (2015) which researched 289 teachers in national primary schools and Chinese national primary schools in the southwestern part of Penang discovered that there are five main factors of stress role among teachers and they are student misconduct, role burden, time constraints and resources, lack of appreciation and interpersonal relationships. In this study, it is found that these five factors contributed to moderate stress level among the teachers.

Furthermore, the study of Mohd Faizul Mohd Noor, Mohd Saifulkhair Omar and Fauzi Hussin (2017) conducted on 105 Muslim teachers in Kuala Nerus District, Terengganu revealed the level of stress amongst teachers between two categories of schools which are A category schools and B category schools. The stress level of teachers from A category schools is at moderate level while the teachers in the B category schools are at low level.

As a foundation for this study, the conceptual framework was based on Kahn's Theory (Kahn, Wolfe, Quinn, Snoek, \& Rosenthal, 1964) and the upgraded model by Kahn and Byosiere's (1992). The Kahn's Theory by Kahn et al. (1964) were used as the baseline theory to see the influence of selected factors on role stress among national school primary teachers in Malaysia. This theory was developed by Robert Louis Kahn, an American psychologist and a social scientist. He was said to be the father of modern research on organizational theory and research. Kahn served in the University of Michigan from 1948 to 1976 as a lecturer and subsequently as a director of the Survey Research Centre.

In the context of this study, role stress is the result of an emphasis on the organization that involves the policy, direction, self-esteem, resources and goals of an organization that will determine whether the individual can survive or not in performing his or her role as a teacher. Role conflict is a situation where an individual is forced to perform tasks based on rules, rules, insistence of individual or other groups and tasks that need to be given priority. Role ambiguity as well is an individual situation that is unclear about the expectations of the organization against it, the time allocation, the limits of authority and the real responsibility. The last is role overload is the situation when an individual is involved with the elements of the period of work, responsibilities, expectations and commitments that are beyond his or her ability.

In addition, another foundation for this study was based on Kahn and Byosiere's (1992) process of stress development in organizations. This model presented the wider perspective on the stress process which involved relationship among stressors, responses to stress and consequences of stress. In other words, this model provides more details aspects of stress identification and management particularly experienced by workers in most organizations. In specific, stressors in organizational life comprised of two main aspects which are physical and psychosocial (role ambiguity, role conflict and role overload). Then this model has highlighted the responses to 


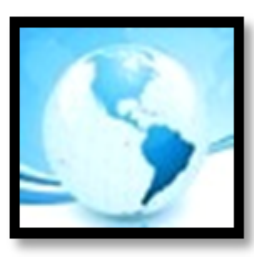

\section{MALAYSIAN ONLINE JOURNAL OF EDUCATIONAL MANAGEMENT (MOJEM)}

stress by workers in the form of behavioural, psychological and physiological responses. All these responses have consequently resulted in several impact such as health and illnesses, organizational effectiveness and performance in other life roles as the factors that to be managed by individuals and organizations in order to function and operate effectively. The following Figure 1 presents the conceptual framework of this study.

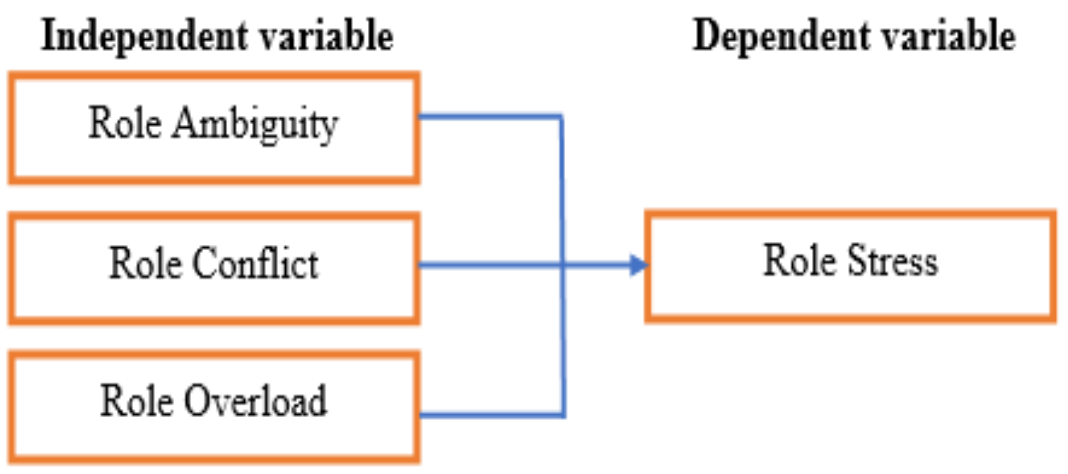

Figure 1. Conceptual framework (Source: Kahn et al. , 1964; Kahn et al. ,1992).

Based on the previous literatures that described the concepts and relevant relationships among the variables, this study will verify on the following research hypotheses:

$\mathrm{H}_{1}$ : There is significant relationship between role conflict and role stress among national primary school teachers. $\mathrm{H}_{2}$ : There is significant relationship between role ambiguity and role stress among national primary school teachers.

$\mathrm{H}_{3}$ : There is significant relationship between role overload and role stress among national primary school teachers.

\section{METHOD}

\section{Research Design}

In order to achieve the aim of this study, quantitative research design has been applied through the use of survey method. Researchers have used the survey method by distributing questionnaires to the targeted sample in the field work. Questionnaire has been identified to be the best instrument to get findings for this study on the level of stress among the national primary school teachers. In addition, field studies were used to illustrate the nature of Ex post facto (causal effect) that occur in this study in order to make the right assumption (Mooi \& Sarstedt, 2011). In addition, researchers have also applied cross sectional survey methods based on adapted questionnaires.

\section{Population \& Sampling}

This research was conducted among primary schools' teachers working in Jerantut, Pahang, Malaysia. The total population of primary school teachers in this place is 1132 teachers from 14 primary schools which consists of various demographic background. In order to carry out this research, a proper number of sampling has to be determined in order to make proper generalization on the population as a whole. The sample size was calculated using formula by $\mathrm{g}^{*}$ power software before the selection of primary school teachers in this study was done. Simple random sampling methods were utilized and the samples were divided as to produce balance proportion of each gender in the sample in order to be as close to the target population as possible (Salkind, 2010). Prior to that, to 


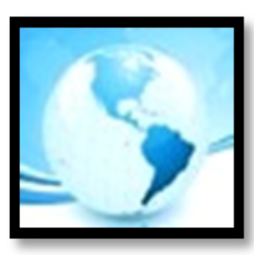

\title{
MALAYSIAN ONLINE JOURNAL OF EDUCATIONAL MANAGEMENT (MOJEM)
}

determine the number of samples to be used, the researchers used the $\mathrm{g}^{*}$ power software. Determining the number of samples through $\mathrm{g}$ * power is based on the number of independent variables. Based on the results of the

analysis by $\mathrm{g}^{*}$ power as shown in Figure 2, the number of samples required for this study was 89 samples. However, the researchers have used a sample of 150 samples, taking into account the possible drop out factors in this study. Out of the total of 150 teachers, 89 were female and 61 were male teachers.

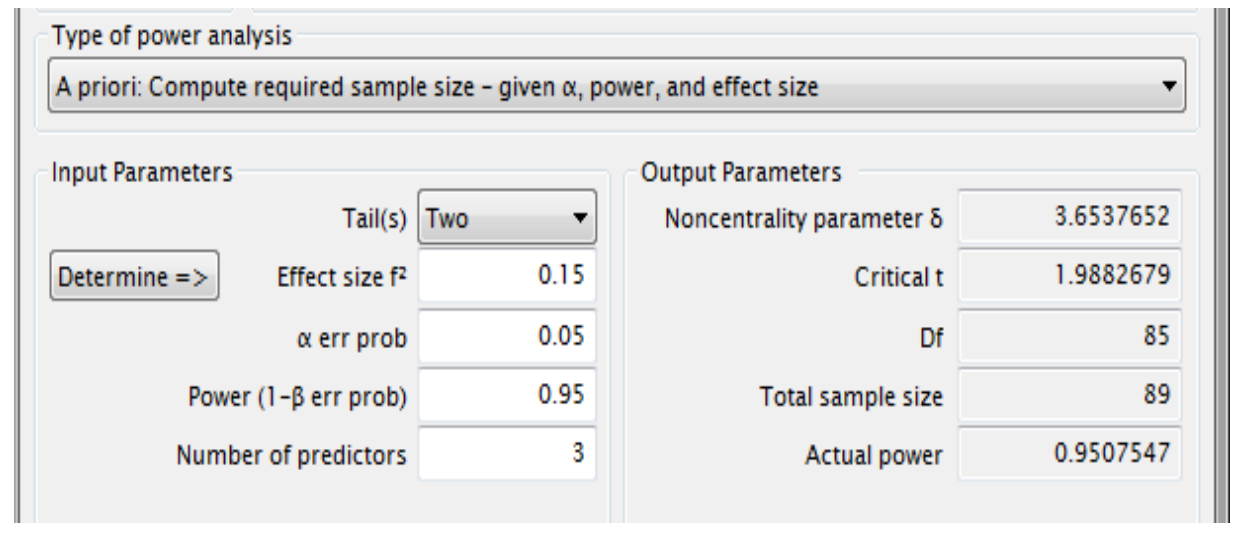

Figure 2. Samples size with $\mathrm{G}^{*}$ Power analysis

\section{Instrumentation}

For this study, a questionnaire was distributed to 150 teachers from 14 primary schools in Jerantut, Pahang. The questionnaire was adapted from various previous studies where the questionnaire by $\mathrm{Hu}, \mathrm{Hu}$, and King (2017) was adapted to measure the role stress constraints. The questionnaire by Conley and You (2013) was also adapted to measure the role conflicts constructs whereas the role ambiguity constructs was adapted from questionnaires by Sahadev, Purani, and Panda (2017). Furthermore, the role overload constructs was adapted from the questionnaire by Thiagarajan, Chakrabarty, and Taylor (2006). The questionnaire prepared for this research used 5 point Likert scale that are 1= strongly disagree, 2 = disagree, $3=$ uncertain, $4=$ agree, and $5=$ strongly agree. The questionnaire was divided into 5 sections comprising of the following parts:

\author{
Section A : Demographic respondents \\ Section B : Role Stress \\ Section C : Role Conflicts \\ Section D : Role Ambiguity \\ Section E : Role Overload
}

\section{Data Collection Procedure}

The data was collected through distribution of questionnaires among teachers from the 14 primary schools in Jerantut, Pahang, Malaysia. At the initial stage, permission was obtained by the Education Planning and Research Division, Ministry of Education Malaysia to conduct the research and the official letter was addressed to all principles and head teachers of the schools. Then, all the respondents were given the opportunity to fill up the questionnaires within three days before the researcher came and collected back the questionnaires. Within the time frame given, respondents were able to ask for any assistance in understanding the questionnaires if needed. 


\section{Data Analysis Procedure}

The data obtained from the questionnaire was analysed using IBM SPSS software for the basic statistical information. Descriptive statistical analysis was used to obtain mean values, mode and standard deviations. For inferential analysis, researchers applied Smart PLS software. It was used to determine the validity and reliability of the instrument and to test the hypothesis of the study (Ringle, Wende, \& Will, 2005). PLS-SEM analysis encompasses two forms of valuation that are evaluation of measurement model (outer model) and assessment of structural model (inner model). Evaluation of measurement model aimed to provide evidence of the reliability and validity of the constructs and the temporary guidance of the assessment structural models was aimed to assess the model's ability to explain variance for each endogenous latern construct (Hair, Sarstedt, Ringle, \& Mena, 2012). Modeling parameters and appraisal estimates are made using PLS algorithm procedure, bootstraping and blindfolding based on the guidance by Hair et al., (2011).

\section{Validity and Reliability}

By referring to Fraenkel and Wallen (2013) validity is the resolution, the meaningful truth and the usability of an instrument which ultimately allows it to be predicted through the data obtained. According to Ghazali Darussalam and Sufean Hussin (2018), validity of an instrument is achieved when the instrument can measure what it was supposed to measure. Based on Fornell and Larcker (1981), an instrument is said to have a validity convergence if it meets three conditions; all individual item cross loading values exceeding 0.7 , composite reliability values of not less than 0.8 and AVE values exceeding 0.5. The findings show that all these conditions have been achieved thus this instrument has the convergence validity needed (Refer to Table 1).

Table 1

Individual item value, composite value and AVE

\begin{tabular}{|c|c|c|c|c|}
\hline Variables & Item & Cross loading & Composite value & AVE value \\
\hline \multirow{7}{*}{ Role Stress (RS) } & BSP1 & 0.773 & 0.935 & 0.671 \\
\hline & BSP2 & 0.848 & & \\
\hline & BSP3 & 0.858 & & \\
\hline & BSP4 & 0.863 & & \\
\hline & BSP5 & 0.829 & & \\
\hline & BSP6 & 0.776 & & \\
\hline & BSP7 & 0.784 & & \\
\hline \multirow[t]{5}{*}{ Role Conflict (RC) } & CKP1 & 0.836 & 0.926 & 0.716 \\
\hline & CKP2 & 0.843 & & \\
\hline & CKP3 & 0.839 & & \\
\hline & CKP4 & 0.861 & & \\
\hline & CKP5 & 0.852 & & \\
\hline \multirow[t]{5}{*}{ Role Ambiguity (RA) } & DKP1 & 0.929 & 0.980 & 0.908 \\
\hline & DKP2 & 0.978 & & \\
\hline & DKP3 & 0.980 & & \\
\hline & DKP4 & 0.912 & & \\
\hline & DKP5 & 0.962 & & \\
\hline \multirow[t]{6}{*}{ Role Overload (RO) } & EBP1 & 0.971 & 0.984 & 0.911 \\
\hline & EBP2 & 0.934 & & \\
\hline & EBP3 & 0.986 & & \\
\hline & EBP4 & 0.944 & & \\
\hline & EBP5 & 0.948 & & \\
\hline & EBP6 & 0.942 & & \\
\hline
\end{tabular}




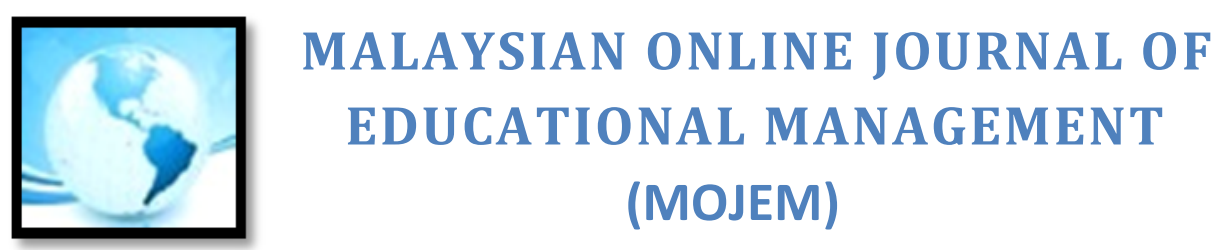

According to Kerlinger (1973) reliability is the degree of conformity and confidence of an instrument with a stable, consistent, cordial and consistent character. Researchers have to conduct the instrument reliability test as it is very crucial to test and analyse the variables through the alpha coefficient. Thus, a test was conducted to determine the value of alpha coefficient through Cronbach's alpha value. The Cronbach's alpha value obtained will then be interpreted based on the strength of association according to Hair, Babin, Money, and Samouel (2003) as shown in table below:

Table 2

Rule of thumb on Cronbach's alpha coefficient sizes

\begin{tabular}{cc}
\hline Cronbach's Alpha coefficient range & Strength of association \\
\hline$<0.6$ & Poor \\
$0.6-<0.7$ & Moderate \\
$<0.7-<0.8$ & Good \\
$<0.8-<0.9$ & Very good \\
$0.9<$ & Excellent \\
\hline
\end{tabular}

Based on the results, the Cronbach's Alpha value of all constructs are greater than 0.900 . Thus, it indicates excellent level of reliability of the instrument. The Cronbach's Alpha coefficient of each construct is as shown in the table below:

Table 3

The value of Cronbach's Alpha coefficient by constructs

\begin{tabular}{ll}
\hline Construct & Cronbach's Alpha coefficients \\
\hline Role Stress & 0.980 \\
Role Conflict & 0.990 \\
Role Ambiguity & 0.996 \\
Role Overload & 0.918 \\
\hline
\end{tabular}

\section{FINDINGS}

Based on the analyses that have been done, the following results were obtained in order to achieve the research objectives of this study that are (i) To identify the level of stress among the national primary school teachers? and

(ii) To determine if there is any significant relationships between the variables of role conflict, role ambiguity and role overload with role stress among national primary school teachers?

\section{Demographic information of Participants}

Table 4

Demographic data

\begin{tabular}{lllccc}
\hline No. & \multicolumn{1}{c}{ Item } & Categories & Frequency & Percentage \% & Total \\
\hline 1. & Gender & Man & 73 & 48 & 150 \\
& & Women & 77 & 52 & 150 \\
$2 . \quad$ Education level & Certificates & 4 & 3 & 4 \\
& & Diploma & 6 & 89 &
\end{tabular}




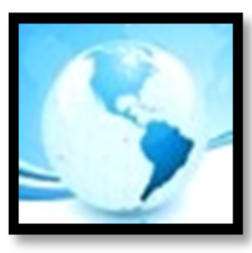

3.

3. Services duration 5-10 years

10-15 years

Over 15 years

4. Areas involved in

Malay Language teaching

English
MALAYSIAN ONLINE JOURNAL OF

EDUCATIONAL MANAGEMENT

(MOJEM)

Science

Mathematics

Islamic Education

Physical Education

Music

Other areas
26

45

79

22

17

18

21

15

7

2

48
18

30

52

15

11

12

14

10

5

1

32

As shown in Table 4, the demographic distribution indicates that the sample may represent population well. Respondents distribution by gender somewhat balanced where 73 of them are man (48\%) and 77 respondents are women (52\%). In terms of education level, the majority have of them have bachelor's degree that are 134 (89\%). Others have master's $6(4 \%), 6(4 \%)$ diploma and 4 (3\%) certificates. The range of services over 15 years represents the largest part of the sample that comprised of 79 (52\%) respondents while service duration of 10 to 15 years are $45(30 \%)$ and service period of 5 to 10 years are $26(18 \%)$. Data for the areas involved in teaching are Malay language 22 (15\%), English 17 (11\%), Science 18 (12\%), Mathematics 21 (14\%), Islamic Education 15 (10\%), Music 2 (1\%) and other areas with the highest number of $48(32 \%)$.

\section{Level of Stress Among The National Primary School Teachers}

The findings show that the mean value of the four constructs is within the range of 2.186 to 3.425 with the standard deviation of 0.743 to 0.943 based on the five-points Likert Scale. As shown on Table 5, the level of role stress among the teachers is at moderate level. These answer the research question on the level of stress among the national primary school teachers. By referring to Table 4 it can be seen that every constructs are at moderate level where the mean for level of role stress is 3.262, the mean for level of role conflict is 3.386 , the mean for level of role ambiguity is 2.186 and the level for role of overload is 3.425 .

Table 5

Descriptive Analysis

\begin{tabular}{lccc}
\hline \multicolumn{1}{c}{ Construct } & Mean & Standard Deviation & Level \\
\hline Role Stress & & 0.904 & Moderate \\
Role Conflict & 3.262 & 0.943 & Moderate \\
Role Ambiguity & 3.386 & 0.743 & Moderate \\
Role Overload & 2.186 & 0.744 & Moderate \\
\hline
\end{tabular}

In sum, the results show that the level of role stress among the national primary school teachers are at moderate level with the specific constructs of role conflict, role ambiguity and role overload also indicate the moderate level.

Relationships between the Variables Of Role Conflict, Role Ambiguity And Role Overload With Role Stress Among National Primary School Teachers

The following Figure 3 shows the inclusion of three independent variables into the Smart PLS route model where it has contributed 37.3 percent to the change of the dependent variable which is role stress. In addition, hypotheses tested using the Smart PLS route model analysis has resulted in three important findings as shown in Table 6 . The 


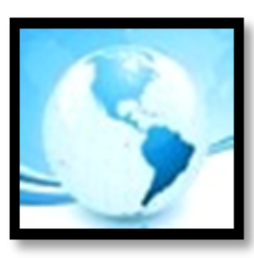

\section{MALAYSIAN ONLINE JOURNAL OF EDUCATIONAL MANAGEMENT (MOJEM)}

role conflict has a significant relationship towards role stress. The proof can be seen in the beta value of 0.212 whereas the $t$ value is $2.640(B=0.212, t=2.640)$. Thus, role conflict $(B=0.212, p<0.05)$ has become a predictor for the dependant variables of role stress. Therefore, this research accepted the research hypothesis that there is significant positive relationship between role conflict and role stress among national primary school teachers. In other words, the change in role conflict will subsequently affecting the change in role stress.

Based on Figure 3 also, the results show that role ambiguity has a significant relationship towards role stress. The proof can be seen in the beta value of 0.219 whereas the $t$ value is $2.701(\beta=0.219, t=2.701)$. Variable of role ambiguity $(\beta=0.219, p<0.05)$ has become a predictor for the dependant variables of role stress. Therefore, this research accepted the research hypothesis that there is significant relationship between role ambiguity and role stress among national primary school teachers. This result also indicated that the change in role ambiguity will followed by change in role stress among national primary school teachers.

Finally, role overload also indicated a significant relationship towards role stress. The proof can be seen in the beta value of 0.372 whereas the $t$ value is $4.364(B=0.372, t=4.364)$. Variable of role overload $(B=0.372, p<0.05)$ has become a predictor for the dependant variables of role stress. Therefore, this research has accepted the research hypothesis that there is significant relationship between role overload and role stress among national primary school teachers. In other words, the change in role overload will subsequently affecting the change in role stress among the national primary school teachers.

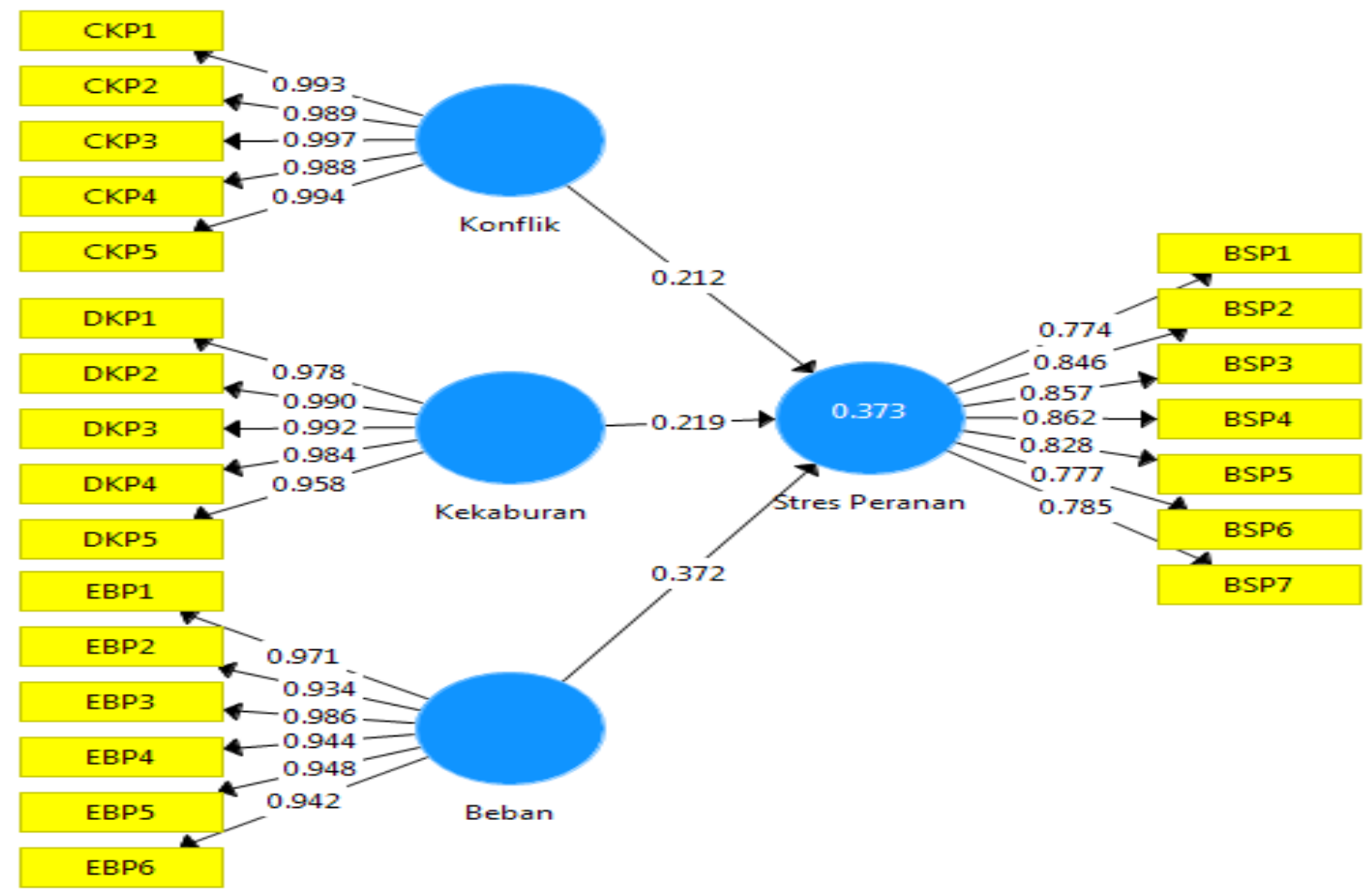

Figure 3. Analysis of the SmartPLS route model

The findings have confirmed that role conflicts, role ambiguity and role overload have acted as important predictors for the variable of role stress in this research. The composition of these three variables has contributed to the total of $37.3 \%$ of the role stress component as shown from the value of $R_{2}=0.373$. Besides that, the findings also indicate that role overload variable is the most powerful predictors that influence the role stress compared to 


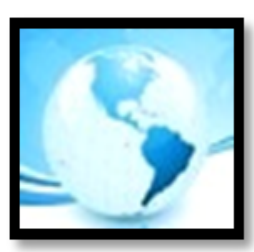

role conflicts and role ambiguity. The details presented in Table 6 shows the Beta (ß) value, t-value and significant value for all these three variables of role conflict, role ambiguity and role overload.

Table 6

Findings for research hypothesis

\begin{tabular}{lcccc}
\multicolumn{1}{c}{ Relationship } & Beta, $\boldsymbol{B}$ & t Value & P Value & Result \\
\hline Conflict > Role Stress & 0.212 & 2.640 & 0.009 & Significant \\
Ambiguity > Role Stress & 0.219 & 2.701 & 0.007 & Significant \\
Overload $>$ Role Stress & 0.372 & 4.364 & 0.000 & Significant \\
\hline
\end{tabular}

$* p<0.05$

Table 6 have indicated that variable of role conflict $(B=0.212, p<0.05)$ has become a predictor for the dependant variables of role stress. Variable of role ambiguity $(B=0.219, p<0.05)$ has become a predictor for the dependant variables of role stress. Variable of role overload $(\beta=0.372, p<0.05)$ has become a predictor for the dependant variables of role stress. Thus, the analyses that have been done have accepted the following research hypotheses:

$\mathrm{H}_{1}$ : There is significant relationship between role conflict and role stress among national primary school teachers. $\mathrm{H}_{2}$ : There is significant relationship between role ambiguity and role stress among national primary school teachers.

$\mathrm{H}_{3}$ : There is significant relationship between role overload and role stress among national primary school teachers.

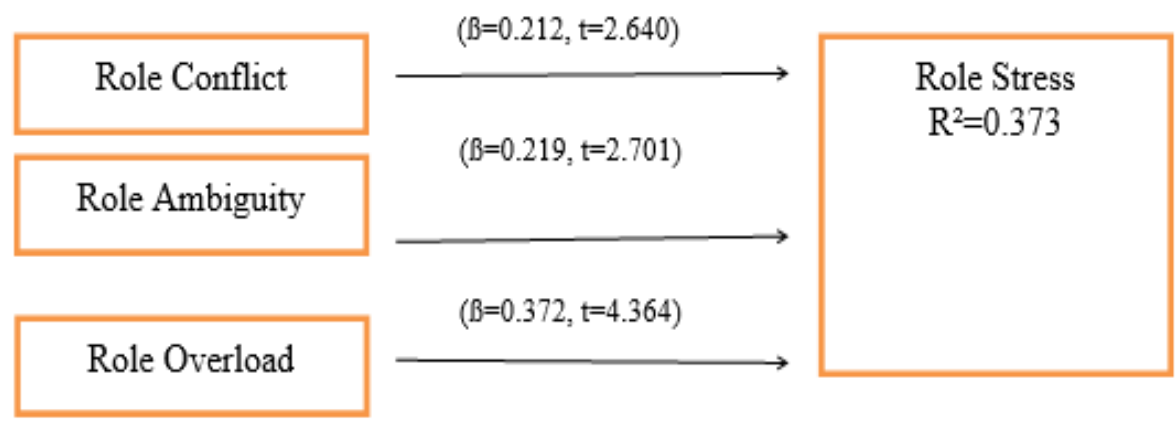

Figure 4. Summary of analysis of research hypotheses

As a conclusion, the variables of role conflict, role ambiguity and role overload have shown significant relationship with the variable role stress as shown in Figure 4 . Based on the value $R_{2}$ of 0.373 , it indicates that $37.3 \%$ of the variation in role stress can be explained by the variation in role conflict, role ambiguity and role overload.

\section{IMPLICATION}

Overall, this study will bring practical implications to the relevant organizations, namely schools district offices, state education offices and the Ministry of Education. The findings can be used as guidance and references by particularly the school administrators and the Deputy Education District in addressing and managing issues related to stress among teachers. This effort will be achieved if these relevant stakeholders pay close attention to some of the key aspects of addressing the issues. The early efforts need to be taken by these stakeholders is to identify issues related to physiological and psychological aspect. Physiological aspect is a reaction or physical change experienced by individuals who experiencing stress. According to Weinberg and Gould (2011), there are various 


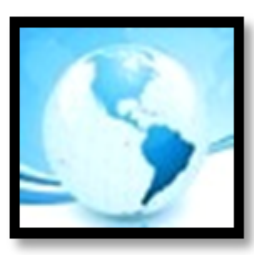

\section{MALAYSIAN ONLINE JOURNAL OF EDUCATIONAL MANAGEMENT (MOJEM)}

responses or changes that can be experienced by individuals experiencing stressful roles. Early detection of physiological aspects can help the stakeholders to take specific actions to prevent the role stress among teachers.

The psychological aspects according to Hockenbury and Hockenbury (2010) are things that relate to the feelings and thoughts of an individual. Thus, stakeholders are encouraged to create harmonious working environment and work together to create team work culture within the organization. According to Spiegel and Torres (1994), teamwork culture can benefit many teams and members in the team. If viewed from the point of the team itself, it will be able to improve productivity, improve workmanship and improve moral and working morale. While from the individual point of view, it can reduce the risk of facing stressful role as responsibility in the team will be shared. Within a team, staff will feel themselves valued through sharing of abilities and shared experiences. Therefore, team members will always strive to produce high quality work and be able to create a strong atmosphere. In addition, it is encouraged for an organization to create a group that can be called as a colleague of co-workers. Among these colleagues' role are to provide support and motivation to friends who are facing problems in their life.

Theoretically, based on the results of this study too, it shows that role overload variables have become a major factor of role stress compared to the other two independent variables of role conflict and role ambiguity. Hence, stakeholders need to focus and prioritize initiatives in reducing the role overload or job burden among teachers. It can be done by revising back the distribution of duties and responsibilities among teachers so that it will be balance and fairly distributed. With more equitable and balanced distribution of duties and responsibilities, it will reduce discontent and anger among teachers due to role stress. Every assignment and tasks among teachers have to be properly guided with more flexibility in its implementation and execution.

\section{DISCUSSION AND CONCLUSION}

Based on the findings of this study, it is proven that role conflicts, role ambiguity and role overload can act as predictor variables to role stress. By referring to the research population, this finding also shows that national primary school teachers were able to manage role conflicts, role ambiguity and role overload well to avoid role stress based on the moderate level of stress indicated in the results.

The findings of this study contribute great implications especially to the research theory, research method and organization context. From the findings, it is shown that the primary school teachers have the ability to manage role conflicts, role ambiguity and role overload in order to control the level of role stress from the indicated data of moderate level. The findings support the findings of Richard (2012); Nagra \& Arora (2013); Fadia M. Nasser (2015); Nur Izzaty Mohamad, Azman Ismail, Mohamad Shahril Azwan Mohamad Rozi, \& Sholihien Ahmad (2015).

From the perspective of research methodology, it is proven that the level of validity and reliability is excellent. This situation has helped researchers to produce a credible and accurate research. Whereas from the organization 's perspective, the results of this study can be used as a guide in addressing and controlling issues related to stress in the workplace especially in educational organizations which generally involves teachers. This can be achieved if the top management of organizations focuses more on certain aspects such as trainings courses which can assist in improving teachers' competencies. Aspects that can be integrated in the training courses can include identifying elements of pressure, psychology and also stress signals.

In addition, the top management should also emphasize on the element of spirituality in addressing stress issues. This is in line with the study done by Lucchetti et al. (2014), lyer et al. (2015) and Zahra et al. (2016).

Furthermore, the top management should always encourage members of the organization to exercise teamwork. Being able to work as a team is a promising way in establishing positive relationships among themselves besides it may bring healthy collaboration in achieving the main mission of the organization. In order to build this teamwork, 


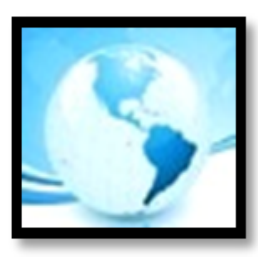

\section{MALAYSIAN ONLINE JOURNAL OF EDUCATIONAL MANAGEMENT (MOJEM)}

the top management needs to know how to delegate their employees' jobs according to their expertise to ensure job satisfaction among employees (teachers) and ultimately reducing their stress level. Being able to achieve this situation can ultimately produce more enthusiastic employees, thus making them be more confident in performing their duties.

In making this study an impactful study, some aspects have been taken into consideration. Among the aspects to be given utmost attention are the aspects of the research method used. In this study, researchers utilize the crosssectional method. Through this method it produces some more solid, relevant and comprehensive study findings (Hair, 2003; Zikmund, 2012). However, this cross-sectional method does not detect in-depth issues or the relationship factors among the variables. This is because it relies heavily on instruments or questionnaires that were built prior to the study. Therefore, it does not measure the relationship between specific indicators of role stress elements.

The use of Smart PLS route model analysis focuses only on the explanation of role stress variance among national primary school teachers based on the variables involved but there are still other variables that can be attributed, for example gender, location, work experience and others. This study only involved teachers of national primary schools in the district of Jerantut, Pahang. Besides, the samples that were randomly selected is also one of the limitations to this study. Therefore, the findings can only explain the pattern of relationship between the variables in general and cannot be generalized to different organizational backgrounds.

In order to improve this study, it is recommended that future researchers identify more personal and organizational characteristics which can clearly demonstrate the similarities and differences in role stress. Additionally, the design of the selected study needs to be more robust and not limited to a particular timing. The future researchers should involve more areas and more samples so that the nature and degree of relationship flexibility among the variables are stronger. Besides, it also involves teachers of various fields and expertise.

Furthermore, it is proposed that future studies should explore other independent variables such as stress types, pressure forms and others as they are also seen as important predictor variables. In addition to independent variables, dependent variables are also other potential variables such as quitting, burnout, job satisfaction and many more. With the addition of this dependent variable, it can produce a better, precise and steady finding.

Without our realization, role stress is becoming a huge issue in the educational organization. This issue should be given more attention and should be monitored prudently by top managements. Although this study shows that the level of role stress among national primary school teachers is moderate, it is inevitable that this issue truly exists and needs to be addressed wisely. This issue needs to be addressed because it can affect the individual's ability both physically and mentally. If role stress can be handled wisely, it will indirectly reduce the pressure of an individual. This is because, if the individual is exposed to stress, it can affect the performance of the individual and at the same time will directly affect the organization.

Top managements should be aware that their staffs are invaluable assets. As a normal human being, employees have their own emotions, feelings, responsibilities and energy. As top management, they should not simply point their fingers to their staff should they fail to perform their assigned tasks. A better approach is the humanistic approach where it helps enhances the staff's performance and commitment to the task. Management that are able to create the right phenomena and environment in producing enthusiastic employees can be considered as an excellent management. 


\section{REFERENCES}

Abang, M. A. (2012). Strategies for handling stress among secondary school teachers in Kuching/Samarahan (Unpublished Master Dissertation). University Malaysia Sarawak, Malaysia. Retrieved from https://ir.unimas.my/id/eprint/622/.

Abdullah, M. D. (2011). Malaysian Islamic Education: Issues and challenges. Paper presented at the meeting of Ministry of Education Malaysia, National Islamic Education Congress, Kuala Lumpur.

Barber, M., \& Mourshed, M. (2007). How the world's best-performing school systems come out on top. Retrieved from www.mckinsey.com/clientservice/socialsector/resources/pdf/Worlds_School_systems_final.pdf

Beehr, T. A., Walsh, J. T., \& Taber, T. D. (1976). Relationships of stress to individually and organizationally valued states: Higher order needs as a moderator. Journal of Applied Psychology, 61(1), 41-47.

Conley, S., \& You, S. (2013). Role stress revisited: Job structuring antecedents, work outcomes and moderating effects of locus of control. Educational Management Administration \& Leadership, 42(2), 184-206.

Fadia, M. N. (2015). Teacher stress and coping: The role of personal and job characteristics. Procedia - Social and behavioural Sciences, 185(2015),374-380.

Fornell, C., \& Larcker, D. F. (1981). Evaluating structural equation models with unobservable variables and measurement error. Journal of Marketing Research, 18(1), 39-50.

Fraenkel, J. R., \& Wallen, N. E. (2013). How to design and evaluate research in education. Journal of Chemical Information and Modeling, 53(9), 1689-1699.

Ghazali, D., \& Sufean, H. (2018). Research methodology in education: Research practices and analysis. Kuala Lumpur: University of Malaya Press.

Great Life Physio and Rehabilitions. (2012). Bulletin of Great Life Physio and rehabilitations. Petaling Jaya, Malaysia.

Hair, Jr. J. F., Black, W. C., Babin, B. J., \& Anderson, R. E. (2009). Multivariate Data Analysis. Upper Saddle River: Prentice Hall.

Hair, J., Babin, B., Money, A., \& Samouel, P. (2003). Essentials of business research Methods. USA: Lehigh Publishing.

Hair, J. F., Sarstedt, M., Ringle, C. M., \& Mena, J. A. (2012). An assessment of the use of partial least squares structural equation modeling in marketing research. Journal of the Academy of Marketing Science, 40(3), 414-433.

Hockenbury, D. H., \& Hockenbury, S. E. (2010). Introduction to psychology as a biological science (5 ${ }^{\text {th }}$ Ed.). USA: Worth Custom Publishing.

Hu, H.-H., Hu, H.-Y., \& King, B. (2017). Impacts of misbehaving air passengers on frontline employees: role stress and emotional labor. International Journal of Contemporary Hospitality Management, 29(7), 1793-1813. 


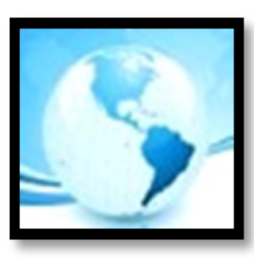

\section{MALAYSIAN ONLINE JOURNAL OF EDUCATIONAL MANAGEMENT (MOJEM)}

Iyer, R. D., \& Mahesh, D. (2015). Workplace spirituality and role stress among nurses in India. IOSR Journal of Nursing and Health Science, 4(4), 2320-1940.

Johari, H., \& Noornazifah, M. S. (2012). A study of stress among primary school teachers in Permas Jaya zone, Johor Bahru from the personality aspect. Journal of Educational Psychology and Counseling, 5(1), $97-112$.

Kahn, R. L., Wolfe, D. M., Quinn, R. P., Snoek, J. D., \& Rosenthal, R. A. (1964). Organizational stress: Studies in role conflict and ambiguity. New York: Wiley.

Kahn, R. L., \& Byosiere, P. B. (1992). Stress in organizations. In M. D. Dunnette \& L. M Hugh (Eds.), Handbook of industrial and organizational psychology. Palo Alto, CA: Consulting Psychologists Press.

Kerlinger, F. N. (1973). Foundation of Behavioral Research. ( $2^{\text {nd }}$ ed.). New York: Holt, Rinehart and Winston.

Lucchetti, G., Lucchetti, L. G., Oliveira, G. R., Crispim, D., Pires, S. L., Gorzoni, M. L., \& Koenig, H. G. (2014). Nursing home care: Exploring the role of religiousness in the mental health, quality of life and stress of formal caregivers. Journal of Psychiatric and Mental Health Nursing, 21(5), 403-413.

Mohd Fadzli Abu Bakar., Janet, H. S. C., Irdiana, S. H., \& Nazrah, J. (2005). Teachers' stress in education and its resolution. Paper presented at the Educational Seminar 2005, UTM Faculty of Education.

Mohd Faizul Mohd Noor., Mohd Saifulkhair Omar., \& Fauzi, H. (2017). Relationship of school climate and secondary school teachers' stress in Kuala Nerus, Terengganu. Proceedings of the ICECRS, 1(1), 39-48.

Mooi, E., \& Sarstedt, M. (2011). A concise guide to market research: The process, data, and methods using IBM SPSS statistics. Heidelberg: Springer.

Nagra, V., \& Arora, S. (2013). Occupational stress and health among teacher educators. International Journal of Advanced Research in Management and Social Sciences, 2(8), 1-13.

National Teaching Service Union. (2017). Bulletin of National Teaching Service Union. Kuala Lumpur, Malaysia.

Norashid Othman., \& Hamzah Md. Omar. (2014). Job load and teachers' teaching motivation in secondary schools at Ranau. Journal for Educational Thinker, 5(1), 35-57.

Nur Izzaty Mohamad., Azman Ismail., Mohamad Shahril Azwan Mohamad Rozi., \& Sholihien Ahmad. (2015). Job stress and its relationship with workers' health: Empirical study at police contingent in Peninsular Malaysia. Geografia: Malaysian Journal of Society \& Space, 11(10), 63-75.

Ooi, C. H., \& Aziah Ismail. (2015). Schools' upper management support towards teachers' work stress in National Schools and Chinese National Schools. Jurnal Kepimpinan Pendidikan, 2(2), 42-57.

Ministry of Education Malaysia. (2013) The Malaysian Education Development Plan (PPPM) 2013 - 2025. Putrajaya: Ministry of Education.

Richards, J. (2012). Teacher Stress and Coping Strategies: A National Snapshot. Educational Forum, 76(3), $299-316$.

Ringle, C. M., Wende, S., \& Will, A. (2005). SmartPLS 2.0 M3. Hamburg: University of Hamburg. 
Rizzo, J. R., House, R. J., \& Lirtzman, S. I. (1970). Role conflict and ambiguity in complex organizations. Administrative Science Quarterly, 15(2), 150-163.

Saedah Siraj., M. Sani Ibrahim., \& Rajendran, N. (2012). Malaysian teachers' competency standard. Retrieved from http://repository.um.edu.my/25208/.

Salkind, N. J. (2010). Encyclopedia of Research Design. Thousand Oaks: SAGE Publication, Inc.

Spiegel, J., \& Torres, C. (1994). Manager's official guide to team working. San Diego, CA: Pfeiffer \& Co.

Sahadev, S., Purani, K., \& Panda, T. K. (2017). Service employee adaptiveness: Exploring the impact of role stress and managerial control approaches. Employee Relations, 39(1), 45-67.

Tajulashikin Jumahat., Fazura Mohd Noor., \& Mohd Burhan Ibrahim. (2017). Factors determining stress among teachers: Mubaligh primary schools in Kuala Lumpur. Jurnal Kurikulum \& Pengajaran Asia Pasifik, 1(2), 35-67.

Thiagarajan, P., Chakrabarty, S., \& Taylor, R. D. (2006). A confirmatory factor analysis of Reilly's role overload scale. Educational and Psychological Measurement, 66(4), 657-666.

Weisberg, R. S., \& Sagie, A. (1999). Teachers' physical, mental and emotional burnout: Impact on intention to quit. The Journal of Psychology Interdisciplinary and Applied, 133(3), 333-339.

Weinberg, R. S., \& Gould, D. (2011). Foundations of Sport and Exercise Psychology. Champaign IL: Human Kinetics.

Zahra Taheri-Kharameh., Mohammad Abdi., Reza Omidi Koopaei., Mostafa Alizadeh., Vahid Vahidabi., \& Hesam Mirhoseini. (2016). The relationship between religious-spiritual well-being and stress, anxiety, and depression in university students received. Health, Spirituality \& Medical Ethic, 3(1), 30-35.

Zikmund, W. G. (2012). Business Research Methods. (7 $7^{\text {th }}$ ed.). USA: Cengage Learning. 